\title{
OPTIMALIZACE OBJ EMOVÉ HMOTNOSTI POLYESTEROVÉ IZOLAČNÍ DESKY V ZÁVISLOSTI NA SOUČINITELI TEPELNÉ VODIVOSTI
}

\author{
OPTIMIZATION OF BULK DENSITY OF THE POLYESTER INSULATION BOARDS \\ ACCORDING TO COEFFICIENT OF THERMAL CONDUCTIVITY
}

\author{
Ing. Čermák J an; prof. RNDr. Ing. Št’astník Stanislav, CSc.
}

\begin{abstract}
ABSTRAKT
V tomto článku je popsána výroba izolačních desek z odpadních polyesterových vláken spojených bikomponentními vlákny. Při výrobě lze připravit požadovanou objemovou hmotnost vyrobené izolační desky dávkováním suroviny a jejím stlačením. Právě objemová hmotnost je jedním z důležitých faktorů, které ovlivňují hodnotu součinitele tepelné vodivosti izolační desky. Funkční závislost hodnoty součinitele tepelné vodivosti na objemové hmotnosti desky je popsána $\mathrm{v}$ experimentální části článku.
\end{abstract}

Kličcová slova: Polyesterová vlákna, součinitel tepelné vodivosti, objemová hmotnost, izolační deska.

\section{ABSTRACT}

This article describes the production of insulation boards of polyester fiber waste associated bicomponent fibers. In the production we can prepare the desired bulk density of insulation board made of raw material by dosing and the compression. Currently bulk density is one of the important factors that affects the value of the thermal conductivity of the insulation board. The functional dependence of the thermal conductivity on bulk density board is described in the experimental section.

Key words: Polyester fibers, thermal conductivity, bulk density, insulation board.

\section{IZOLAČNÍ ROHOŽE Z ODPADNÍHO POLYESTERU}

Odpadní polyesterová vlákna se jeví jako vhodná surovina pro výrobu nových izolačních materiálů. Původní polyesterové výrobky musí být nejprve rozvlákněny na jednotlivá vlákna a poté opětovně spojeny v soudržnou rohož. Pro spojení je využito technologie bikomponentních vláken, kdy jsou polyesterová a bikomponentní vlákna dokonale homogenizována v určitém poměru tak, aby se jejich struktura důkladně propojila. Využívá se bikomponentních vláken, které mají nízkou teplotu tání $\left(t_{t} \approx\right.$ $140^{\circ} \mathrm{C}$ ). Po rozdružení polyesterových vláken a jejich dokonalé homogenizaci s vlákny polyesterovými dochází k nanesení ve vrstvách na speciálně upravený rošt, který má takovou sítových otvorů, aby jím nanesená vlákna nemohla propadávat a mohl jím prostupovat horký vzduch. Právě pomocí horkého vzduchu o teplotě asi $140^{\circ} \mathrm{C}$ dochází ke spojení struktury bikomponentních a polyesterových vláken, kdy se bikomponentní vlákna nataví a tím se vytváří soudržná prostorová struktura rohože. Objemovou hmotnost vyráběných rohoží lze rrídit množstvím nanesené směsi vláken na rošt a jejich stlačením na požadovanou tloušt'ku.

Polymer esteru vzniká chemickou reakcí (polykondenzací) ze dvou vstupních komponent, ze kterých je vyroben polykondenzát, který se zvlákňuje z taveniny do šachty, následně dlouží, poprrípadě sdružuje do kabelu, který se dále řeže na stř̌ž nebo trhá na trhanec. Vznikají různě jemná, profilovaná, 
popřípadě bikomponentní vlákna. Polyester vytváří ve srovnání s polyamidem relativně tuhá vlákna. Používá se ve směsích s bavlnou, vlnou a stř̌ží do mykaných a česaných přízí. [1]

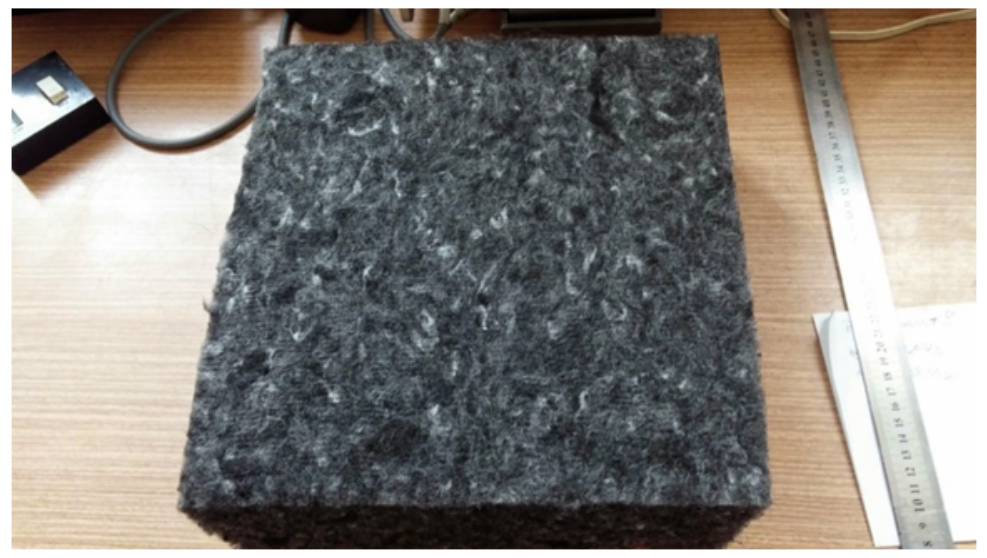

Obr. 1 Vzhled izolační rohože vyrobené ze směsi polyesterových a bikomponentních vláken.

\subsection{Popis experimentu}

Cílem experimentu bylo optimalizovat objemovou hmotnost izolační desky z polyesterových vláken tak, aby výsledná deska měla nejmenší možný součinitel tepelné vodivosti $\lambda\left[\mathrm{Wm}^{-1} \mathrm{~K}^{-1}\right]$. Dále byl proveden experiment, ve kterém byl zkoumán vliv vložení hliníkové fólie do struktury desky na součinitel tepelné vodivosti $\lambda$. Hliníková fólie (nadále označovaná $\mathrm{Al}$ folie) má díky svému složení a barvě zcela odstranit nebo omezit přenos tepla sáláním v izolační desce a pomoci ke zmenšení hodnoty součinitele tepelné vodivosti $\lambda$ izolace. Tepelná vodivost $\lambda$ byla měřena na deskovém stacionárním př́istroji HOLOMETRIX 300 postupem podle [2].

\section{Měření bylo rozděleno do tř́ etap:}

1. Měření PES izolačních rohoží s různou objemovou hmotností bez $\mathrm{Al}$ fólie,

2. měření PES izolačních rohoží s různou objemovou hmotností s jednou Al fólií vloženou uprostřed rohože,

3. měření PES izolačních rohoží s různou objemovou hmotností se dvěma Al fóliemi umístěnými v $1 / 3$ a ve $2 / 3$ tloušt'ky rohože(viz obrázek 2).

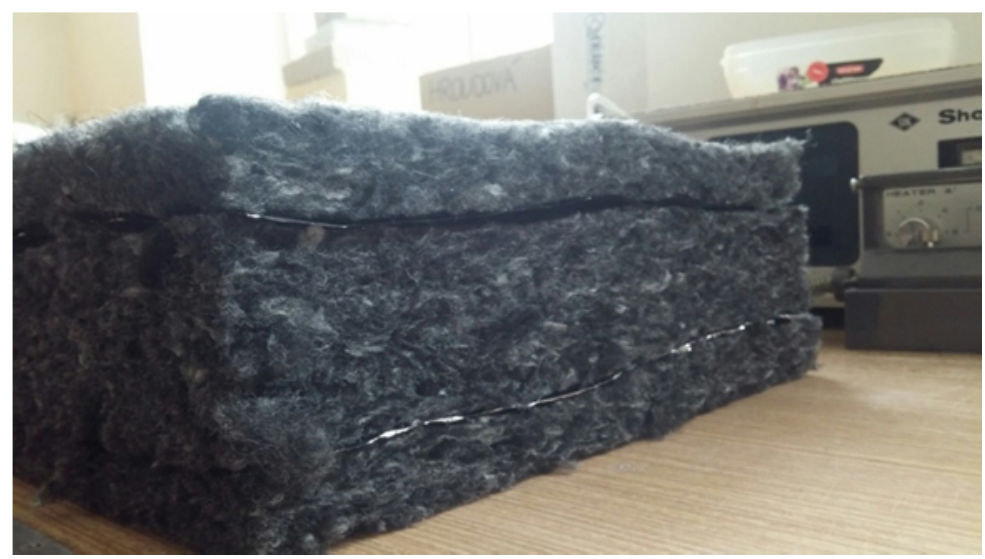

Obr. 2 Vzhled izolační rohože s vloženými dvěma Al fóliemi v 1/3 a ve 2/3 tloušt'ky rohože.

\subsection{Naměřené a vypočtené hodnoty}

Všechny naměřené a vypočtené hodnoty byly zaznamenány přehledně do tabulek a grafů. 


\subsubsection{Naměřené hodnoty}

\begin{tabular}{|c|lrr|c|c|}
\hline \multirow{4}{*}{ Vzorek 1} & $d$ & $=$ & $100 \mathrm{~mm}$ & $\varphi \lambda\left[\mathbf{W m}^{-1} \mathbf{K}^{-1}\right]$ & Uspořádání vzorku \\
\cline { 2 - 6 } & $m=$ & $168,660 \mathrm{~g}$ & 0,0544 & PES \\
\cline { 2 - 6 } & $V=$ & $0,009 \mathrm{~m}^{3}$ & 0,0455 & PES+Al \\
\cline { 2 - 6 } & $\rho_{d}=$ & $19 \mathrm{~kg} / \mathrm{m}^{3}$ & 0,0495 & PES+2xAl \\
\hline
\end{tabular}

\begin{tabular}{||l|lr|c|c|}
\hline \multirow{4}{*}{ Vzorek 2} & $d=$ & $90 \mathrm{~mm}$ & $\varphi \lambda\left[\mathbf{W m}^{-1} \mathbf{K}^{-1}\right]$ & Uspořádání vzorku \\
\cline { 2 - 6 } & $m=$ & $168,660 \mathrm{~g}$ & 0,0499 & PES \\
\cline { 2 - 6 } & $V=$ & $0,008 \mathrm{~m}^{3}$ & 0,0446 & PES+Al \\
\cline { 2 - 6 } & $\rho_{d}=$ & $21 \mathrm{~kg} / \mathrm{m}^{3}$ & 0,0466 & PES+2xAl \\
\hline
\end{tabular}

\begin{tabular}{|c|l|l|c|c|}
\hline \multirow{4}{*}{ Vzorek 3} & $d=$ & $80 \mathrm{~mm}$ & $\varphi \lambda\left[\mathbf{W m}^{-1} \mathbf{K}^{-1}\right]$ & Uspořádání vzorku \\
\cline { 2 - 6 } & $m=$ & $168,660 \mathrm{~g}$ & 0,0456 & PES \\
\cline { 2 - 6 } & $V=$ & $0,007 \mathrm{~m}^{3}$ & 0,0432 & PES+Al \\
\cline { 2 - 6 } & $\rho_{d}=$ & $23 \mathrm{~kg} / \mathrm{m}^{3}$ & 0,0442 & PES+2xAl \\
\hline
\end{tabular}

\begin{tabular}{|c|c|c|c|c|c|}
\hline \multirow{4}{*}{ Vzorek 4} & $d$ & 75 & $\mathrm{~mm}$ & $\varphi \lambda\left[\mathrm{Wm}^{-1} \mathbf{K}^{-1}\right]$ & Uspořádání vzorku \\
\hline & $m=$ & $=168,660$ & $\mathrm{~g}$ & 0,0438 & PES \\
\hline & $V=$ & 0,007 & $\mathrm{~m}^{3}$ & 0,0420 & $\mathrm{PES}+\mathrm{Al}$ \\
\hline & $\rho_{d}=$ & 25 & $\mathrm{~kg} / \mathrm{m}^{3}$ & 0,0423 & $\mathrm{PES}+2 \mathrm{xAl}$ \\
\hline
\end{tabular}

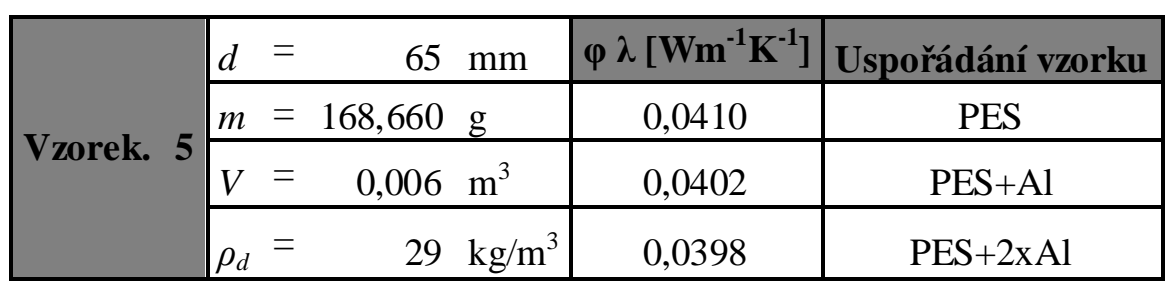

\begin{tabular}{|c|lrr|c|c|}
\hline \multirow{4}{*}{ Vzorek 6 } & \multicolumn{1}{|l}{$=$} & $50 \mathrm{~mm}$ & $\varphi \lambda\left[\mathbf{W m}^{-1} \mathbf{K}^{-1}\right]$ & Usporáádání vzorku \\
\cline { 2 - 6 } & $m=$ & $168,660 \mathrm{~g}$ & 0,0379 & PES \\
\cline { 2 - 6 } & $V=$ & $0,005 \mathrm{~m}^{3}$ & 0,0383 & PES+Al \\
\cline { 2 - 6 } & $\rho_{d}=$ & $37 \mathrm{~kg} / \mathrm{m}^{3}$ & 0,0388 & PES+2xAl \\
\hline
\end{tabular}

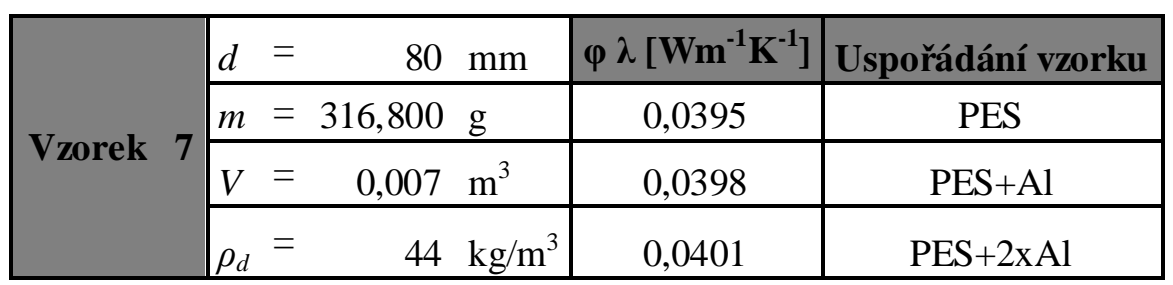

Tab. 1-7 Přehled hodnot součinitele tepelné vodivosti $\lambda \mathrm{v}$ závislosti na objemové hmotnosti $\rho_{d}$. 


\begin{tabular}{|c|c|c|c|}
\hline $\begin{array}{c}\text { Relativní vlh kost } \\
\text { prostředí } \varphi \text { [\%] }\end{array}$ & $\mathbf{0}$ & $\mathbf{5 5}$ & $\mathbf{8 0}$ \\
\hline$\lambda\left[\mathbf{W m}^{-1} \mathbf{K}^{-1}\right]$ & 0,0498 & 0,0544 & 0,0586 \\
\hline
\end{tabular}

Tab. 8 Vliv relativní vlhkosti prostředí $\varphi$ na hodnotu součinitele tepelné vodivosti izolační rohože $\lambda$.

Měření bylo provedeno na vzorku polyesterové izolační rohože o tloušt'ce $d=100 \mathrm{~mm}$ ve vysušeném stavu, dále na tzv. vzduchosuchém vzorku dlouhodobě uloženém v laboratorním prostředí a také na vzorku, který byl kondiciován v klimatické komoře o teplotě $23^{\circ} \mathrm{C}$ a relativní vlhkosti $80 \%$.

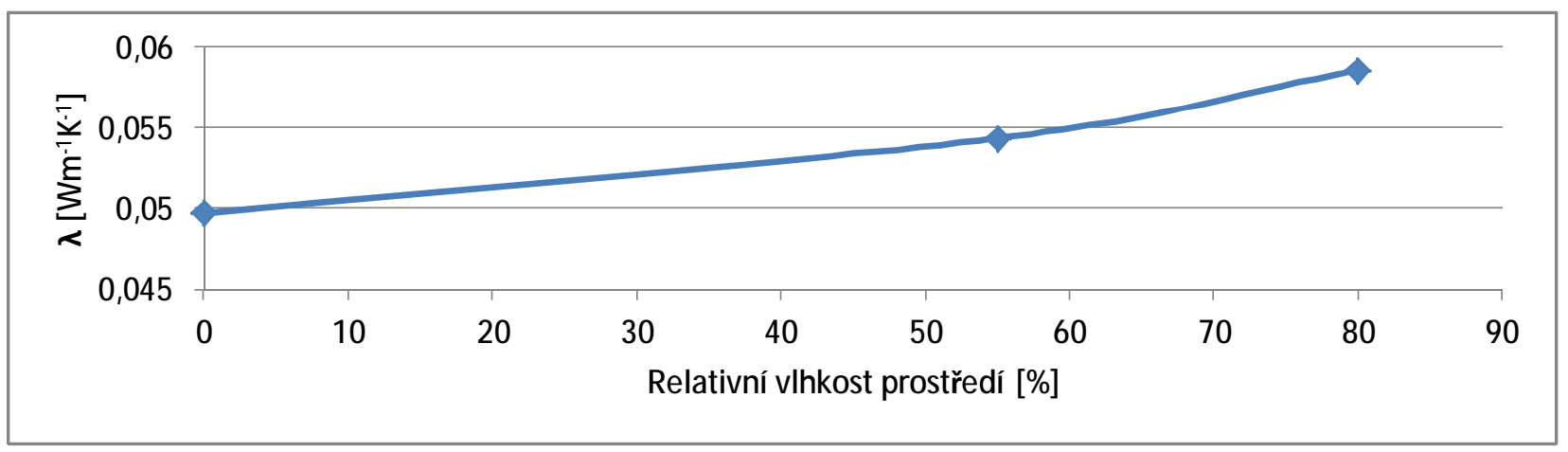

Graf 1 Závislost relativní vlhkosti okolního prostředí $\varphi$ na hodnotě součinitele tepelné vodivosti $\lambda$.

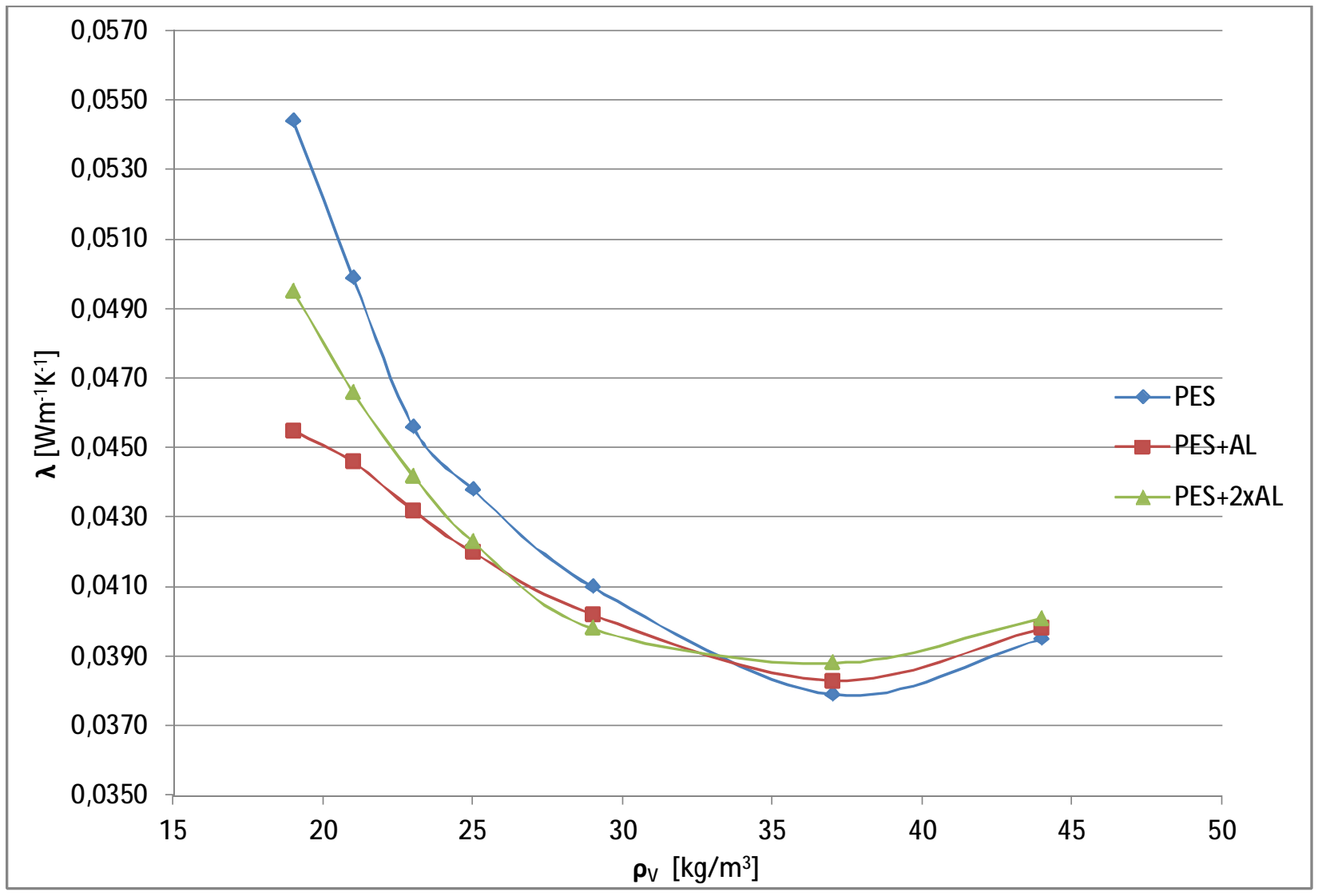

Graf 2 Průběh hodnot součinitele tepelné vodivosti $\lambda v$ závislosti na objemové hmotnosti izolační desky $\rho$. 


\subsection{Vypočtené hodnoty}

Pro potřebu zjištění optimální objemové hmotnosti polyesterové rohože byla provedena aproximace naměřných hodnot metodou nejmenších čtverců. Tímto postupem byl vyčíslen polynom $g(x)$, který těsně aproximuje měřené hodnoty. Pomocí polynomické funkce $g(x)$ byla vyčíslena hodnota součinitele tepelné vodivosti pro objemové hmotnosti rohoží v rozmezí 20 až 49 kg/m³.

\begin{tabular}{|c|c|c|c|}
\hline \multicolumn{4}{|c|}{$g(x)=a x^{4}+b x^{3}+c x^{2}+d x+e$} \\
\hline$x$ & $f_{(x)}$ & $g_{(x)}$ & $\left(f_{(x)}-g_{(x)}\right)^{2}$ \\
\hline 23 & 0,0456 & 0,0456 & $3,99699.10^{-19}$ \\
\hline 25 & 0,0438 & 0,0438 & $1,38878.10^{-18}$ \\
\hline 29 & 0,041 & 0,0410 & $4,82801 \cdot 10^{-19}$ \\
\hline 37 & 0,0379 & 0,0379 & $3,43914 \cdot 10^{-20}$ \\
\hline 44 & 0,0395 & 0,0395 & $1,47659.10_{-21}$ \\
\hline \multicolumn{3}{|c|}{$\mathrm{L}_{\min }=$} & $2,30715.10^{-18}$ \\
\hline
\end{tabular}

Tab. 9 Vyčíslení funkce $g(x)$ a odchylky naměřených a aproximovaných hodnot $(f(x)-g(x))^{2}$.

Poznámka: Hodnota x zobrazuje objemovou hmotnost $\rho_{\mathrm{v}}$, hodnota $f(x)$ zobrazuje naměrené hodnoty součinitele tepelné vodivosti $\lambda$, hodnota $g(x)$ zobrazuje vypočtené hodnoty součinitele tepelné vodivosti $\lambda$, hodnota $(f(x)-g(x))^{2}$ zobrazuje odchylku naměrených a aproximovaných hodnot.

$$
\mathbf{g}_{(\mathbf{x})}=6,25 \cdot 10^{-8} \mathbf{x}^{4}-7,64 \cdot 10^{-6} \mathbf{x}^{3}+3,74 \cdot 10^{-4} \mathbf{x}^{2}-9,11 \cdot 10^{-3} \mathbf{x}+0,133
$$

Tab. 10 Tvar aproximační funkce $g(x)$ závislosti součinitele tepelné vodivosti $\lambda$ na objemové hmotnosti $\rho$.

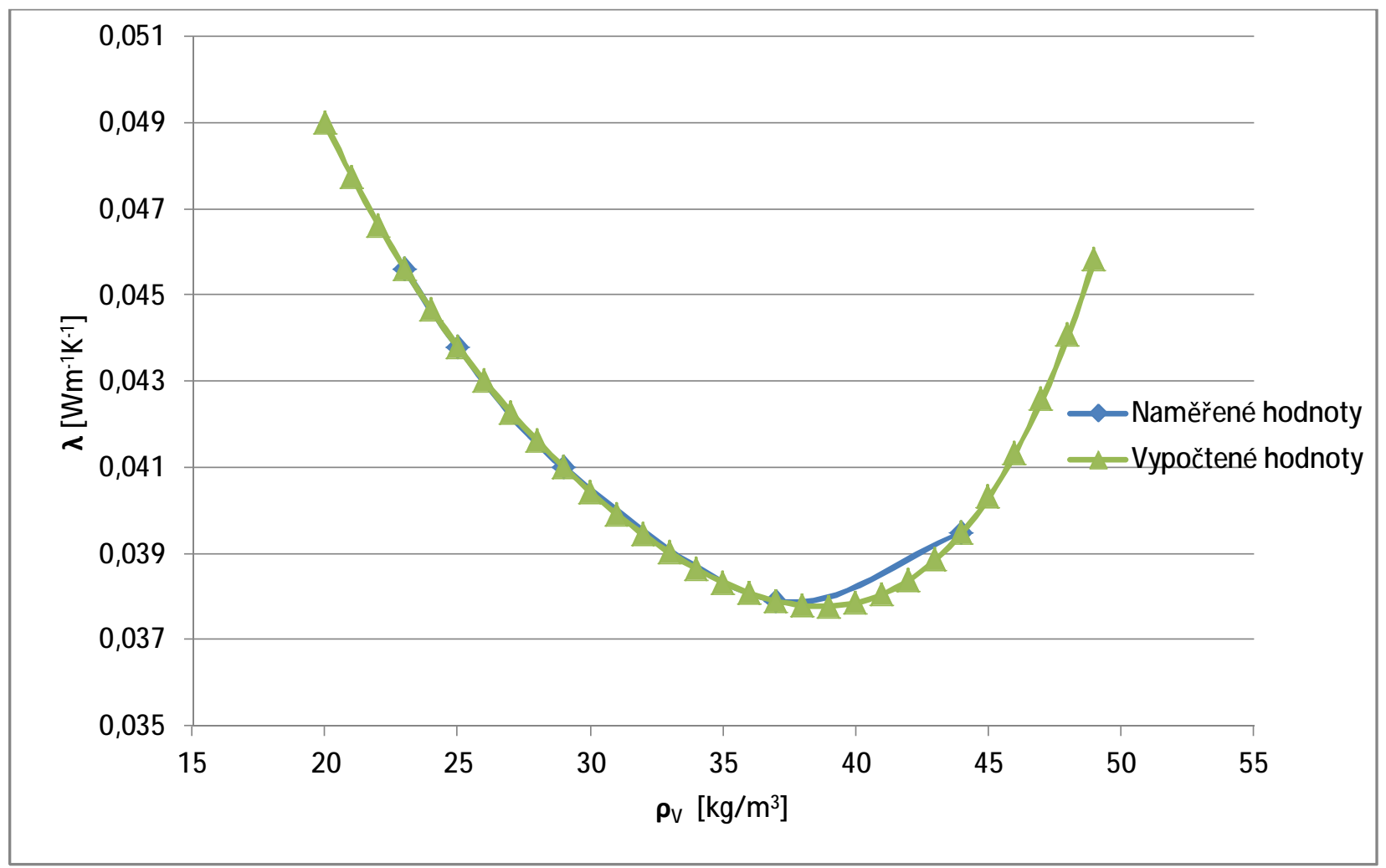

Graf 3 Průběh závislosti součinitele tepelné vodivosti $\lambda$ podle aproximace(metodou nejmenších čtverců) vưči experimentálním hodnotám. 


\subsection{Závěr}

V provedeném experimentu byl sledován vliv objemové hmotnosti polyesterové izolační rohože na hodnotě součinitele tepelné vodivosti $\lambda$. Dále byl zjištěn vliv vložení jedné, respektive dvou vrstev hliníkové fólie do izolační rohože. Výsledky experimentu jsou seřazeny v tabulkách $1 \div 7$ a v grafu 2 . Z naměřených hodnot vyplývá poznatek, že hodnoty součinitele tepelné vodivosti závisí na objemové hmotnosti $\rho_{V}$. Tento experiment ověřuje vlastnosti izolačních rohoží s objemovou hmotností v rozmezí $19 \div 44 \mathrm{~kg} / \mathrm{m}^{3}$. Z grafu 2 je patrné, že hodnota součinitele tepelné vodivosti s rostoucí objemovou hmotností nejprve klesá a od hodnoty objemové hmotnosti $37 \mathrm{~kg} / \mathrm{m}^{3}$ se nadále zvyšuje. Cílem tohoto experimentu bylo prokázat optimální objemovou hmotnost s nejnižší možnou hodnotou součinitele tepelné vodivosti $\lambda$.

Vliv vložených $\mathrm{Al}$ fólií je nejvíce patrný při nízkých objemových hmotnostech zkoumaného materiálu. U izolačních rohoží s nižší objemovou hmotností do $30 \mathrm{~kg} / \mathrm{m}^{3}$ dochází účinkem velmi lehké struktury $\mathrm{k}$ přenosu tepla prouděním, proto je po vložení $\mathrm{Al}$ fólie hodnota součinitele tepelné vodivosti $\lambda$ nižší. Dochází tak $\mathrm{k}$ rozdělení desky pro vzduch nepropustnou fólií a tak nedochází $\mathrm{k}$ přenosu tepla prouděním v celé tloušt'ce desky, ale pouze $\mathrm{v}$ jednotlivých částech rozdělených $\mathrm{Al}$ fólií. Při vyšších objemových hmotnostech izolační rohože je vliv Al fólií nízký. Z toho lze usoudit, že daný materiál je nepropustný pro infračervené záření, proto v něm nedochází k přenosu tepla sáláním. Naopak vliv Al fólie je od hodnoty objemové hmotnosti $37 \mathrm{~kg} / \mathrm{m}^{3}$ nepřináší zlepšení, což je patrně způsobeno narušením struktury izolační desky a přerušením její celistvosti. $\mathrm{Z}$ uvedených výsledků lze prokázat, že vložení A fólie do izolační desky nezlepšuje její hodnotu součinitele tepelné vodivosti při vyšších objemových hmotnostech.

Nejpříznivější hodnotu součinitele tepelné vodivosti $\lambda=0,379 \mathrm{Wm}^{-1} \mathrm{~K}^{-1}$ projevuje vzorek bez vložené fólie s objemovou hmotností $37 \mathrm{~kg} / \mathrm{m}^{3}$. Dále s rostoucí objemovou hmotnostíse zvyšuje i hodnota součinitele tepelné vodivosti. V tomto experimentu tedy byla stanovena optimální objemová hmotnost izolační rohože z polyesterových vláken $37 \mathrm{~kg} / \mathrm{m}^{3}$. Dále se ukazuje, že vliv vložených $\mathrm{Al}$ fólií se projevuje jako zanedbatelný, u optimální objemové hmotnosti dokonce jako nepříznivý.

Vyhledáním extrému aproximační funkce se ukazuje, že optimální objemová hmotnost polyesterové rohože činí $39 \mathrm{~kg} / \mathrm{m}^{3}$, kdy je hodnota součinitele tepelné vodivosti nejnižší - $\lambda=0,3778 \mathrm{Wm}^{-1} \mathrm{~K}^{-1}$. Odchylka aproximované funkce od naměřených hodnot se pohybuje $\mathrm{v}$ řádech $10^{-21}$ až $10^{-18}$. Lze zjistit, že je odchylka zanedbatelná a vypočtené hodnoty odpovídají reálným hodnotám naměřeným. Výpočet byl proveden pouze u vzorku PES bez vložených Al fólií, protože u tohoto vzorku byla naměřena nejmenší hodnota součinitele tepelné vodivosti.

\section{Poděkování}

Tento článek byl vytvořen za finanční podpory projektu specifického výzkumu VUT Brno s označením FAST-J-15-2797.

\section{Použitá literatura}

[1] Polyesterová vlákna. Škola textilu [online]. [cit. 2015-10-27]. Dostupné z: http://www.skolatextilu.cz/elearning/467/textilni-terminologie-zboziznalstvi/vlakna-prize-anite/Polyesterova-vlakna.html.

[2] ČSN 72 7306:1995 - Stanovení součinitele tepelné vodivosti stavebních materiálů a výrobkư. Praha: ÚNMZ, 1995, 18177. 